\title{
Characteristics of Atmospheric Trace Gases, Particulate Matter and Heavy Metal Pollution in Karachi, Pakistan
}

\author{
Durdana Rais Hashmi*, Akhtar Shareef, Razia Begum \\ Email address: \\ drhpakr@yahoo.com (D. R. Hashmi), akhtarshareef@yahoo.com (A. Shareef) \\ ${ }^{*}$ Corresponding author
}

Centre for Environmental Studies, Pakistan Council of Scientific and Industrial Research Laboratories Complex, Karachi, Pakistan

\section{To cite this article:}

Durdana Rais Hashmi, Akhtar Shareef, Razia Begum. Characteristics of Atmospheric Trace Gases, Particulate Matter and Heavy Metal Pollution in Karachi, Pakistan. International Journal of Environmental Monitoring and Analysis. Vol. 5, No. 3, 2017, pp. 73-82.

doi: 10.11648/j.ijema.20170503.12

Received: November 17, 2016; Accepted: November 30, 2016; Published: April 24, 2017

\begin{abstract}
This study was carried out for determination of Aerosol particulate matter $\left(\mathrm{PM}_{10}\right)$, trace gases $\left(\mathrm{SO}_{2}, \mathrm{NO}_{2}, \mathrm{CO}\right)$ and heavy metals $(\mathrm{Zn}, \mathrm{Pb}, \mathrm{Mn}, \mathrm{Cu}, \mathrm{Ni}$ and $\mathrm{Cd})$ in the atmospheric air of Karachi city. Sampling has been done at thirteen locations between during the year of 2014. The total average concentrations of $\mathrm{SO}_{2}, \mathrm{NO}_{2}, \mathrm{CO}$ and $\mathrm{PM}_{10}$ were 65.9, 98.7, 1.49 and $202.14 \mu \mathrm{g} \mathrm{m}^{-3}$, respectively. An atomic absorption spectrophotometer (AAS) was used to determine the trace metal concentrations in the $\mathrm{PM}_{10}$ size fraction. The total average concentrations of $\mathrm{Cd}, \mathrm{Zn}, \mathrm{Pb}, \mathrm{Mn}, \mathrm{Cu}$ and $\mathrm{Ni}$ in $\mathrm{PM}_{10}$ were 0.09 , 2.55, 2.23, 1.92, 2.15 and $1.44 \mu \mathrm{g} \mathrm{m}^{-3}$ respectively. The $\mathrm{Pb}$ concentration in Karachi shows a decreasing tendency, presumably due to the ban on the use of leaded fuel. The overall trace metal concentrations in Karachi are higher than those in European (e.g., Spain, Norway) and East Asian (e.g., Taiwan) locations, but lower than those measured in Southeast Asian (Kanpur, Delhi, Mumbai, India) cities.
\end{abstract}

Keywords: Air Pollution, Trace Gases, Particulate Matter, Heavy Metals

\section{Introduction}

Air pollution is a global hazards and has immense effects on human health, metrology, climatic changes and ecosystem. In developing countries modernization and industrialization increases the use of fossil fuel in many ways and producing environmental damages especially in rapidly growing megacities. Air pollution is one of the serious problems in most of the mega cities of the world, especially in developing countries, which not only experiences a rapid growth of population due to increasing rate of rural urban migration but also industrialization which is accompanied by air, water and vehicular pollution. Exposure to environmental pollution is now an almost an inescapable part of urban life of the world. The proportion of the world population living in the large town or cities has grown about 5 to $50 \%$ during past two decades. Demographers estimate that by the year 2030, approximately two third of the world population will live in large towns or cities [A. J. McMichael. 2000]. The most common air pollutants in the urban environment are Sulphur dioxide $\left(\mathrm{SO}_{2}\right)$, nitrogen oxides $\left(\mathrm{NO}\right.$ and $\mathrm{NO}_{2}$ collectively represented as NOx), carbon monoxide $(\mathrm{CO})$, Ozone $\left(\mathrm{O}_{3}\right)$, suspended particulate matter (SPM), methane and non methane hydrocarbons and trace metals.

Gaseous pollutants have main harmful, effects on health. These pollutants are responsible for changing the atmospheric chemistry and cause environmental damage. Sulphur dioxide $\left(\mathrm{SO}_{2}\right)$ and Nitrogen dioxide $\left(\mathrm{NO}_{2}\right)$ form acids through different chemical reactions in the atmosphere, and subsequently these acids deposited on land and ocean surfaces due to formation of acid rain. It is predicted that the increasing concentration of sulfur dioxide $\left(\mathrm{SO}_{2}\right)$, nitrogen dioxide $\left(\mathrm{NO}_{2}\right)$ and carbon monoxide $(\mathrm{CO})$ in the atmosphere will contribute to global climate change. Several Researches has focused on particulate matter (PM) pollution due to their severe health effects, especially fine particles. A number of epidemiological studies have indicated a strong association between elevated concentrations of inhalable particulate 
$\left(\mathrm{PM}_{10}\right)$ and increased mortality and morbidity [Sicard, P., et al, 2011 and Brook RD et al, 2010].

Particulate matter pollution in the atmosphere primarily consists of micron and sub-micron particles from both anthropogenic (motor vehicles, biomass, fossil fuel burning) and natural sources (windblown soils and sea spray) [Park, S. S., Kim, Y. J., 2005]. The characterization of fine particles has become an important priority of governments, regulators, and researchers due to their potential impact on human health, climate change, global warming, and long-range transport [IPCC (International Panel on Climate Change), 2001].

This study shows the occurrence and characteristics of gaseous $\left(\mathrm{SO}_{2}, \mathrm{NO}_{2}\right.$ and $\left.\mathrm{CO}\right)$ pollutants, level of particulate matter $\left(\mathrm{PM}_{10}\right)$, and trace metals concentrations $(\mathrm{Zn} \mathrm{Pb}, \mathrm{Mn}$, $\mathrm{Cu}, \mathrm{Ni}$ and $\mathrm{Cd}$ ) in the atmospheric air. Also, we compared the trace metal content of $\mathrm{PM}_{10}$ with other part of the world.

\section{Materials and Methods}

\subsection{Study Area}

Karachi lies between $24^{\circ} 45^{\prime} \mathrm{N}$ in longitude and $66^{\circ} 37^{\prime} \mathrm{E}$ in latitude. It has an area of $3,640 \mathrm{~km}^{2}$ and is located along the cost of the Arabian Sea. It is the largest metropolitan city of Pakistan, has an estimated population of over 23.5 million people as reported in 2013. With respect to the population Karachi is the 2nd-largest city in the world Karachi has a moderately temperate climate with a generally high relative humidity that varies from $58 \%$ in December (the driest month) to $85 \%$ in August (the wettest month). In winter, the average temperature of the city is about $21^{\circ} \mathrm{C}$ while in summer it reaches up to $35^{\circ} \mathrm{C}$. Karachi receives about 256 $\mathrm{mm}$ of average annual rainfall [S. H. Sajjad et al, 2010].

Karachi is the financial and commercial capital of Pakistan as well as the major sea port. It plays an important role in the economy of Pakistan and is considered as the economic and financial gateway of Pakistan. Karachi has several large industrial zones such as Karachi Export Processing Zone, Sindh Industrial Trading Estate, Korangi Industrial Area, Landhi Industrial Trading Estate, Northern By-pass Industrial Zone, Bin Qasim and North Karachi industrial zone, located on the fringes of the main city [S. H. Sajjad et al, 2010]. Its primary industries are textiles, pharmaceuticals, steel, and auto-mobiles. Due to industrialization, business activities and employment opportunities Karachi has been facing mass scale rural-urban migration from all over the Pakistan.

\subsection{Ambient Air Monitoring}

\section{Sampling}

Sampling was carried out at thirteen locations consisting of main roads, side road, round about, and open places along the busy roads of Karachi from January to November 2014 for gaseous pollutants and $\mathrm{PM}_{10}$. Selected locations were categorized as Commercial, Residential, Industrial and background areas of the Karachi's environment.

Monitoring of gaseous pollutants were carried out by UV Fluorescent $\mathrm{SO}_{2}$ Analyzer Model AF22 M, NO-NOx Analyzer Model AC 32M and Snifit CO Analyzer (Model 50). These analyzers are considered as reliable for monitoring the pollution level.

$\mathrm{PM}_{10}$ samples were collected on glass fiber filters $(203 \times 254 \mathrm{~mm})$ by using high volume air sampler with an average flow rate of $1.0 \mathrm{~m}^{3} / \mathrm{min}$. Eight hour average sampling was done in duplicate at each location during the year 2011 to 2012 . The high volume is considered a reliable instrument for measuring the weight of $\mathrm{PM}_{10}$ in ambient air (USEPA-Method 40 CFR).

The thirteen sampling locations were selected to reflect the influences from residential, commercial, industrial and heavy traffic sources in the highly populated areas in Karachi: PIB colony, Nazimabad Board Office, PECHS Society, Tower, Tibet Centre, Kiamari, Liaquatabad Market, Empress market, hussainabad, Qazzafi ground, Landhi \#2, Habib bank Chowrangi and PCSIR Colony. The PCSIR colony is about 30 kilometers downwind from main super highway and considered to be an urban background site. Samples were collected on glass fiber filters $(203 \times 254 \mathrm{~mm})$ by using high volume air sampler with an average flow rate of $1.0 \mathrm{~m}^{3} / \mathrm{min}$. Eight hour average sampling was done in duplicate at each location during the year 2014. The high volume is considered a reliable instrument for measuring the weight of $\mathrm{PM}_{10}$ in ambient air (USEPA-Method 40 CFR). Relevant features of air quality stations are shown in Table 1.

Table 1. Description of the sampling locations during the study period in Karachi.

\begin{tabular}{lll}
\hline Location & Code \# & Status of the sites \\
\hline PIB Colony & $\mathrm{R}-1$ & Mainly residential with high traffic \\
Nazimabad Board Office, & $\mathrm{R}-2$ & Mainly residential with moderate traffic \\
PECHS Society & $\mathrm{R}-3$ & Mainly residential with low traffic \\
Tower & $\mathrm{T}-1$ & Commercial area with heavy traffic \\
Tibet Centre & $\mathrm{T}-2$ & Commercial area with heavy traffic \\
Kiamari & $\mathrm{T}-3$ & Commercial area with heavy traffic \\
Liaquatabad Market & $\mathrm{C}-1$ & Commercial / Residential area with heavy traffic \\
Empress Market & $\mathrm{C}-2$ & Commercial / residential area with heavy traffic \\
Hussainabad & $\mathrm{C}-3$ & Commercial / Residential area with heavy traffic \\
Qazzafi ground & $\mathrm{I}-1$ & Industrial area with moderate traffic \\
Landhi \# 2 & $\mathrm{I}-2$ & Industrial area with low traffic \\
Habib Bank Chowrangi & $\mathrm{I}-3$ & Industrial area with heavy traffic \\
PCSIR Colony & $\mathrm{UB}-1$ & Semi urban area with very low traffic \\
\hline
\end{tabular}




\subsection{Monitoring of Trace Gases}

\subsubsection{CO Gas Analyzer (Model 50)}

Concentration of carbon monoxide is measured by Snifit CO Analyzer (Model 50). The Analyzer is ideal for measuring the level of carbon monoxide in ambient air and it samples the surrounding air and shows the detected concentrations of carbon monoxide in ppm. During all the measurements, the meter was kept at about $1.2 \mathrm{~m}$ above the ground level. At each site, level of CO in the ambient air was taken at an interval of 02 minutes and a set of various readings was noted.

\subsubsection{UV Fluorescent $\mathrm{SO}_{2}$ Analyzer Model AF22 M}

AF22M, Sulfur dioxide analyzer, capable of measuring sulfur dioxide at ppb level. Applied to $\mathrm{SO}_{2}$ measurement, the universally known UV fluorescent principle consists in detecting the characteristic fluorescence radiation emitted by $\mathrm{SO}_{2}$ molecules. In the presence of a specific wavelength of UV light $(214 \mathrm{~nm})$ the $\mathrm{SO}_{2}$ molecules reach temporary excited electronic state. The subsequent relaxation produces a florescence radiation which is measured by a non-cooled photomultiplier tube (PM).

\subsubsection{NO-NOx Analyzer Model AC 32M}

The Chemiluminescent $\mathrm{NO}-\mathrm{NO}_{2}-\mathrm{NO}_{\mathrm{X}}$ analyzer, model AC32M, capable of measuring nitrogen oxides at ppb levels. Applied to nitrogen oxides measurement, chemiluminescence corresponds to an oxidation of $\mathrm{NO}$ molecules by $\mathrm{O}_{3}$ molecules. The return to a fundamental electronic state of the excited $\mathrm{NO}_{2}$ molecules is made by luminous radiation, detected by the PM tube. The Model AC $32 \mathrm{M}$ is a state-ofthe-art single chamber - single photomultiplier tube design which automatically cycles between the $\mathrm{NO}$ and $\mathrm{NO}_{\mathrm{X}}$ modes.

The new electronics allow enhanced data storage of more than one month of 15 minute averages and total remote troubleshooting diagnostic capabilities via modem.

\subsection{4. $\mathrm{PM}_{10}$ Mass Concentration}

In addition to the determination of elemental concentrations, airborne particle masses of $\mathrm{PM}_{10}$ samples were measured using analytical balance (KERN, ALS 220-4). The filter papers were weighed under controlled conditions of humidity and temperature before and after collection of particulate matter. Weights for the blank filters were also recorded. Prior to weighing, all filter papers (glass fiber filter paper) were left to equilibrate their humidity and temperature conditions for at least 24 hours in a desiccators. The collected particle mass was calculated by subtracting pre-weight from post-weight of the filter.

\subsection{Sample Analysis for Trace Metals}

Acid digestion method for metals determination by Atomic absorption spectrophotometer (Hitachi Z- 8000), with Zeeman Effect background correction was carried out according to a standard procedure. Acid digestion was performed by following these steps: (1) samples of dry filters were dissolved in nitric acid and per-chloric acid (10:4), (2) digestase were evaporated till white fumes arose and reduced to $2-3 \mathrm{~mL}$, (3) the content was filtered through a What-man Filter 42 and the final volume was makeup to $50 \mathrm{~mL}$ by double distilled water.

A series of blanks were prepared using the same digestion method. Metals and reagents used for standard solutions were of $\mathrm{AR}$ grade. The reagents used were $\mathrm{HNO}_{3} 71 \%$ (specific gravity $1.41, \mathrm{~Pb}$ and $\mathrm{Fe} 0.00002 \%$, Mn $0.00004 \%$ while $\mathrm{Cu}$ $0.00001 \%$ ) and $\mathrm{HClO}_{4} 40 \%$ (specific gravity 1.13). The filtrates were analyzed for trace metals using AAS. The trace metal amounts in the samples were calculated by subtracting the blank value for the respective metal.

Before analyzing the samples, the instrument was calibrated for $\mathrm{Zn}, \mathrm{Pb}, \mathrm{Mn}, \mathrm{Cu}$, Ni and $\mathrm{Cd}$. As per the USEPA method 40 CFR, stock solutions (BDH, 1,000 ppm) were used and diluted to the range of working standards for individual metal just before their utilization. Using these working standards, the calibration figures were prepared in the linear range of the optical density $(0.04-0.8)$. The instrument was calibrated at three different levels $(0.5,1.0$, and $1.5 \mathrm{ppm})$ for $\mathrm{Pb}$ and $\mathrm{Cd}$ metals. Whereas, (1, 2 and 2.5ppm) for $\mathrm{Zn}, \mathrm{Cu}, \mathrm{Mn}$ and $\mathrm{Ni}$. Exactly the same extraction and analysis procedure was employed for $\mathrm{PM}_{10}$ filter papers in order to examine the trace metal content of blank filter paper.

\subsection{Quality Assurance}

Precision and accuracy of the results were confirmed through an average value of three replicates for each reading and cross checking of the blank or standard at ten sample intervals. The calibration curves of standard solutions of metals were used to justify the quantification. The minimum detection limits for $\mathrm{Zn} 1.6 \mu \mathrm{g} / \mathrm{m}^{3}, \mathrm{~Pb} \quad 1.2 \mu \mathrm{g} / \mathrm{m}^{3}, \mathrm{Mn}$ $0.9 \mu \mathrm{g} / \mathrm{m}^{3}, \mathrm{Cu} 0.9 \mu \mathrm{g} / \mathrm{m}^{3}$, Ni $0.3 \mu \mathrm{g} / \mathrm{m}^{3}$ and $\mathrm{Cd}$ is $0.02 \mu \mathrm{g} / \mathrm{m}^{3}$ respectively. The precision of the analysis of standard solution was better than $5 \%$ in all the readings.

\section{Results and Discussion}

\subsection{Overview of the Experimental Results}

Assessment of the concentrations of ambient air $\mathrm{PM}_{10}$, trace gases $\left(\mathrm{SO}_{2}, \mathrm{NO}_{2} \mathrm{CO}\right)$, and trace metals $(\mathrm{Zn}, \mathrm{Pb}, \mathrm{Mn}$, $\mathrm{Cu}, \mathrm{Ni}$ and $\mathrm{Cd}$ ) were determined on $\mathrm{PM}_{10}$ size fractions at thirteen locations in Karachi, from January to November 2014. The sampling sites were located at PIB Colony, Nazimabad Board Office, PECHS Society, Tower, Tibet Centre, Kiamari, Liaquatabad Market, Empress Market, Hussainabad, Qazzafi ground, Landhi \# 2, Habib Bank Chowrangi and PCSIR Colony.

The description of the sampling sites are given in Table 1. The concentrations of measured components varied between residential, industrial and semi-urban sites in different areas of Karachi between January and November 2014. Details of the experimental results were given in Tables 2, 3 and 4. 


\subsection{Trace Gases}

Atmospheric trace gases $\left(\mathrm{SO}_{2}, \mathrm{NO}_{2}\right.$ and $\left.\mathrm{CO}\right)$ were measured at thirteen locations in Karachi during the period of January to November 2014. Samples were collected twice in a month at each location. The sampling time was $8 \mathrm{~h}$ for $\mathrm{SO}_{2}, \mathrm{NO}_{2}$ and $1 \mathrm{~h}$ for $\mathrm{CO}$. The samples were collected by analyzers design and fabricated by Environmental S. A France.

The overall average value of $\mathrm{SO}_{2}$ at thirteen sampling locations in Karachi was $60.38 \mu \mathrm{g} \mathrm{m}^{-3}$, which is higher to the annual average of the World Health Organization's (WHO) guideline values for the European Union (WHO 2000: $50 \mu \mathrm{g}$ $\mathrm{m}^{-3}$ ). Because the total sampling period in our study was 11 months [twice a month, $8 \mathrm{~h}$ for $\mathrm{SO}_{2}$ and $\mathrm{NO}_{2}, 1 \mathrm{~h}$ for $\mathrm{CO}$ ]. The highest concentration (94.4 and $89.8 \mu \mathrm{g} \mathrm{m}^{-3}$ ) of $\mathrm{SO}_{2}$ was found in the commercial and industrial areas at location I-3 and $\mathrm{C}-1$, whereas the lowest concentration $\left(17.2 \mu \mathrm{g} \mathrm{m}^{-3}\right)$ was found in the semi-urban area at locationUB-1. The elevated concentration of $\mathrm{SO}_{2}$ in the city center is probably due to the high content of sulfur in fossil fuel.

The total average concentration of $\mathrm{NO}_{2}$ at thirteen locations in Karachi was $108.34 \mu \mathrm{g} \mathrm{m}^{-3}$, which is more than double of the annual WHO guideline value $2005\left(40 \mu \mathrm{g} \mathrm{m}^{-3}\right)$. The $\mathrm{NO}_{2}$ enters the atmosphere from various natural and anthropogenic sources, including lighting, action of microorganisms on nitrogen-based fertilizer, but the most important and major anthropogenic source is the combustion of fossil fuel in traffic. The highest concentration of $\mathrm{NO}_{2}\left(159.2 \mu \mathrm{g} \mathrm{m}^{-3}\right)$ was found in industrial area at location I-3 with high traffic density and industrial emission, whereas the lowest concentration $(31.8 \mu \mathrm{g}$ $\mathrm{m}^{-3}$ ) was found at location UB-1 in semi urban area.

The measured $\mathrm{CO}$ values varied between residential, commercial, industrial, traffic areas and background areas. The highest concentration $\left(2.9,2.5\right.$ and $\left.2.7 \mu \mathrm{g} \mathrm{m}^{-3}\right)$ of $\mathrm{CO}$ was observed at the commercial and industrial site at locations C-1, C-2 and I-3, whereas the lowest value $(0.2 \mu \mathrm{g}$ $\mathrm{m}^{-3}$ ) was found at location UB-1 in background area. The highest concentration of $\mathrm{CO}$ at commercial and industrial sites is presumably due to the incomplete combustion of fossil fuel in faulty vehicles and during different mechanical and industrial processes. However, the overall (11 months at thirteen sampling locations) average value of CO in Karachi was $1.5 \mu \mathrm{g} \mathrm{m}^{-3}$ (1-h sampling time).

\section{3. $P M_{10}$ Concentrations}

The distribution parameters for $\mathrm{PM}_{10}$ for residential, traffic, commercial, industrial and background areas are given in Table 2. The particulate matter concentrations at thirteen locations varied from 89.3 to $288.5 \mu \mathrm{g} / \mathrm{m}^{3}$, for Residential areas 171.3 to $229.6 \mu \mathrm{g} / \mathrm{m}^{3}$, for traffic areas 184.6 to $289.2 \mu \mathrm{g} / \mathrm{m}^{3}$, for Commercial areas 196.6 to $288.5 \mu \mathrm{g} / \mathrm{m}^{3}$, for Industrial areas 182.9 to $278.8 \mu \mathrm{g} / \mathrm{m}^{3}$, for background areas $89.3 \mu \mathrm{g} / \mathrm{m}^{3}$ respectively. In Residential areas $\mathrm{PM}_{10}$ concentrations were higher at locations R-2 $\left(229.6 \mu \mathrm{g} / \mathrm{m}^{3}\right)$ surrounded by shopping centers with food court producing emission due to commercial activities, In Traffic areas $\mathrm{PM}_{10}$ concentrations were higher at locations T-2 $\left(289.2 \mu \mathrm{g} / \mathrm{m}^{3}\right)$ receiving higher concentration of $\mathrm{PM}_{10}$ due to vehicular emission and automobile repairing shops and traffic jams due narrow and congested roads, In commercial areas $\mathrm{PM}_{10}$ concentrations were higher at location C-1 $\left(288.5 \mu \mathrm{g} / \mathrm{m}^{3}\right)$ this location surrounded by roundabouts having automobile repairing shops, unplanned rickshaws stand, and they are receiving higher emissions due to vehicles and commercial activities of super market, In Industrial areas $\mathrm{PM}_{10}$ concentrations were higher at locations I-3 $\left(278.8 \mu \mathrm{g} / \mathrm{m}^{3}\right)$ and receiving higher emissions due to industrial and vehicular emission, whereas in background areas $\mathrm{PM}_{10}$ concentrations were higher at location UB-1 $\left(89.3 \mu \mathrm{g} / \mathrm{m}^{3}\right)$ due to impact of vehicular emission from nearby superhighway. Overall mean concentration of $\mathrm{PM}_{10}$ at various locations of commercial, residential, industrial and background areas was $207.8 \mu \mathrm{g} \mathrm{m}^{-3}$ for Karachi region.

Chuersuwan et al (2008) reported that mass concentrations of 57.6-108.1 $\mu \mathrm{g} \mathrm{m}^{-3}$ for $\mathrm{PM}_{10}$ at four sampling sites in Bangkok, Thailand. The $\mathrm{PM}_{10}$ mass-concentrations in Kanpur, India were almost equal than those were found for Karachi. At three sampling locations in Kanpur, the average $\mathrm{PM}_{10}$ mass concentration was $211 \mu \mathrm{g} \mathrm{m}^{-3}$ and ranged from 80 to $281 \mu \mathrm{g} \mathrm{m}^{-3}$ (Sharma and Maloo 2005). The level of $\mathrm{PM}_{10}$ in Karachi shows that particulate mass mostly derived from fine fraction, which is very harmful for human health.

Table 2. Concentrations of Atmospheric Trace Gases and Particulate Matter at Thirteen locations in Karachi City.

\begin{tabular}{|c|c|c|c|c|c|}
\hline Sampling Location & Code \# & $\mathrm{SO}_{2}$ & $\mathrm{NO}_{2}$ & $\mathrm{CO}$ & $\mathbf{P M}_{10}$ \\
\hline PIB Colony & (R-2) & 47.4 & 72.2 & 0.9 & 197.2 \\
\hline Nazimabad Board Office & $(\mathrm{R}-1)$ & 57.6 & 84.7 & 1.4 & 229.6 \\
\hline PECHS Society & (R-3) & 31.1 & 60.2 & 0.5 & 171.3 \\
\hline Tower & $(\mathrm{T}-1)$ & 61.4 & 114.2 & 1.5 & 184.6 \\
\hline Tibbet Centre & $(\mathrm{T}-2)$ & 81.7 & 146.7 & 2.3 & 289.2 \\
\hline Kiamari & $(\mathrm{T}-3)$ & 37.4 & 73.4 & 1.1 & 200.7 \\
\hline Liaquatabad Market & $(\mathrm{C}-1)$ & 89.8 & 152.2 & 2.9 & 288.5 \\
\hline Empress Market & $(\mathrm{C}-2)$ & 66.7 & 128.2 & 2.5 & 201.7 \\
\hline Hussainabad & $(\mathrm{C}-3)$ & 47.3 & 97.3 & 1.4 & 196.6 \\
\hline Qazzafi ground & $(\mathrm{I}-1)$ & 71.2 & 121.9 & 1.2 & 191.4 \\
\hline Landhi \# 2 & $(\mathrm{I}-2)$ & 82.4 & 136.4 & 1.4 & 182.9 \\
\hline Habib Bank Chowrangi & $(\mathrm{I}-3)$ & 94.4 & 159.2 & 2.7 & 278.8 \\
\hline PCSIR Colony & (UB-1) & 17.2 & 31.8 & 0.2 & 89.3 \\
\hline
\end{tabular}

Units are in $\mu \mathrm{g} \mathrm{m}^{-3}$

Samples were collected twice a month at each location (each location has a total of 22 samples). Sampling time was 8 h for $\mathrm{SO}_{2}, \mathrm{NO}_{2}, \mathrm{PM}_{10}$ and $1 \mathrm{~h}$ for $\mathrm{CO}$ 
Table 3. Concentrations of trace metals at thirteen sampling sites in Karachi for the size fraction PM 10 between January and November 2014.

\begin{tabular}{|c|c|c|c|c|c|c|c|}
\hline Sampling Location & Code \# & Cd & $\mathbf{Z n}$ & $\mathbf{P b}$ & Mn & $\mathrm{Cu}$ & $\mathbf{N i}$ \\
\hline PIB Colony & (R-1) & 0.044 & 1.6 & 1.2 & 1.1 & 1.0 & 0.5 \\
\hline Nazimabad Board Office & $(\mathrm{R}-2)$ & 0.054 & 2.1 & 1.8 & 1.2 & 1.4 & 0.9 \\
\hline PECHS Society & $(\mathrm{R}-3)$ & 0.028 & 1.4 & 1.1 & 0.5 & 0.8 & 1.1 \\
\hline Tower & $(\mathrm{T}-1)$ & 0.073 & 2.2 & 2.1 & 1.3 & 1.1 & 1.5 \\
\hline Tibbet Centre & $(\mathrm{T}-2)$ & 0.094 & 4.5 & 2.9 & 1.9 & 1.4 & 1.7 \\
\hline Kiamari & $(\mathrm{T}-3)$ & 0.062 & 2.0 & 1.8 & 1.5 & 0.7 & 1.1 \\
\hline Liaquatabad Market & $(\mathrm{C}-1)$ & 0.106 & 3.6 & 2.7 & 3.0 & 2.0 & 1.7 \\
\hline Empress Market & $(\mathrm{C}-2)$ & 0.101 & 3.1 & 2.3 & 2.7 & 1.6 & 1.9 \\
\hline Hussainabad & $(\mathrm{C}-3)$ & 0.08 & 2.1 & 2.1 & 2.4 & 1.2 & 1.5 \\
\hline Qazzafi ground & $(\mathrm{I}-1)$ & 0.102 & 2.4 & 1.7 & 1.9 & 2.5 & 2.1 \\
\hline Landhi \# 2 & $(\mathrm{I}-2)$ & 0.104 & 2.9 & 2.0 & 2.1 & 2.2 & 2.6 \\
\hline Habib Bank Chowrangi & $(\mathrm{I}-3)$ & 0.151 & 3.3 & 2.9 & 2.6 & 3.1 & 2.4 \\
\hline PCSIR Colony & (UB-1) & 0.008 & 1.52 & 0.9 & 0.5 & 0.7 & 0.4 \\
\hline
\end{tabular}

All units are in $\mu \mathrm{g} \mathrm{m}^{-3}$.

Samples were collected twice a month at each sampling location (each location has a total 22 samples).

\subsection{Trace Metals Concentrations}

Thirteen samples of particulate matter were collected from the main roads, side road, round about, and open places along the busy roads of Karachi and these locations were categorized as commercial (03 locations), residential (03 locations), Industrial (03 locations), Traffic areas (03 locations) and urban Background zones (01 location) of the Karachi city. Analysis of these particulate matter samples were carried out for Zinc, Lead, Manganese, Copper, Nickel and Cadmium respectively.

Average concentrations for trace metals $(\mathrm{Zn}, \mathrm{Pb}, \mathrm{Mn}, \mathrm{Cu}$, $\mathrm{Ni}$ and $\mathrm{Cd}$ ) at various locations (residential, traffic, commercial, industrial and background areas) are shown in Figures 1, 2, 3, 4, 5 and 6 for the study areas. The highest concentration of $\mathrm{Zn}$ (Table 3) was found $4.5 \mu \mathrm{g} / \mathrm{m}^{3}$ in traffic area, $3.6 \mu \mathrm{g} / \mathrm{m}^{3}$ in commercial area, $3.3 \mu \mathrm{g} / \mathrm{m}^{3}$ in industrial area, $2.1 \mu \mathrm{g} / \mathrm{m}^{3}$ in residential area and $1.5 \mu \mathrm{g} / \mathrm{m}^{3}$ in urban background area, $\mathrm{Pb}$ (Table 3) was found $2.9 \mu \mathrm{g} / \mathrm{m}^{3}$ in traffic and industrial area, $2.7 \mu \mathrm{g} / \mathrm{m}^{3}$ in commercial areas, $1.8 \mu \mathrm{g} / \mathrm{m}^{3}$ in residential area and $0.9 \mu \mathrm{g} / \mathrm{m}^{3}$ in urban background area, Mn was found $3.0 \mu \mathrm{g} / \mathrm{m}^{3}$ in commercial area, $2.6 \mu \mathrm{g} / \mathrm{m}^{3}$ in industrial area, $1.9 \mu \mathrm{g} / \mathrm{m}^{3}$ in traffic areas, $1.2 \mu \mathrm{g} / \mathrm{m}^{3}$ in residential area and $0.5 \mu \mathrm{g} / \mathrm{m}^{3}$ in urban background area, $\mathrm{Cu}$ (Table 3) was found $3.1 \mu \mathrm{g} / \mathrm{m}^{3}$ in industrial area, $2.0 \mu \mathrm{g} / \mathrm{m}^{3}$ in commercial area, $1.4 \mu \mathrm{g} / \mathrm{m}^{3}$ in traffic areas, $1.4 \mu \mathrm{g} / \mathrm{m}^{3}$ in residential area and $0.7 \mu \mathrm{g} / \mathrm{m}^{3}$ in urban background area, Ni (Table 3) found $2.6 \mu \mathrm{g} / \mathrm{m}^{3}$ in industrial area, $1.9 \mu \mathrm{g} / \mathrm{m}^{3}$ in commercial area, $1.5 \mu \mathrm{g} / \mathrm{m}^{3}$ in traffic areas, $1.1 \mu \mathrm{g} / \mathrm{m}^{3}$ in residential area and $0.4 \mu \mathrm{g} / \mathrm{m}^{3}$ in urban background area, Whereas highest concentration of $\mathrm{Cd}$ (Table-3) was found $0.151 \mu \mathrm{g} / \mathrm{m}^{3}$ in industrial area, $0.106 \mu \mathrm{g} / \mathrm{m}^{3}$ in commercial area, $0.094 \mu \mathrm{g} / \mathrm{m}^{3}$ in traffic areas, $0.054 \mu \mathrm{g} / \mathrm{m}^{3}$ in residential area, $0.008 \mu \mathrm{g} / \mathrm{m}^{3}$ in urban background area respectively.

On the average, the decreasing elemental concentration trend for $\mathrm{Zn}$ and $\mathrm{Pb}$ in Karachi was: Commercial > Industrial $>$ Traffic areas $>$ Residential $>$ urban background areas, whereas for $\mathrm{Mn}, \mathrm{Cu}, \mathrm{Ni}$ and $\mathrm{Cd}$ was: Industrial > Commercial $>$ Traffic areas $>$ Residential $>$ urban background areas respectively.
Figure-1 shows the concentration of Zinc in Residential, traffic, Commercial, industrial and background areas of Karachi. Maximum average concentration of zinc $\left(4.5 \mu \mathrm{g} / \mathrm{m}^{3}\right)$ found at location T-2 (traffic area). The average $\mathrm{Zn}$ concentrations varied from $1.4 \mu \mathrm{g} / \mathrm{m}^{3}$ at location $\mathrm{R}-3$ in residential area to $4.5 \mu \mathrm{g} / \mathrm{m}^{3}$ at location $\mathrm{t}-2$ in traffic area (Table 3). The highest value of $\mathrm{Zn}$ at T-2 Tibet Centre was probably due to large parking place for hundreds of vehicles near this round about with very high traffic density. Moreover; the roads are narrow and congested with high traffic density, producing tunnel effect while the lowest value of $\mathrm{Zn}$ at R-3 PECHS Society may be because this is an open place on wide road having low traffic density with low emissions. All the sampling points in traffic and commercial areas were on the busiest intersections in Karachi and are surrounded by multistoried buildings both for commercial offices and residential buildings on main roads and round about having high traffic density.

Figure-2 shows the concentration of lead in Residential, traffic, Commercial, industrial and background areas of Karachi. The high Lead concentration detected indicates the harshness of this toxic metal in the environment. According to USEPA and World Health Organization (2000), the recommended atmospheric limits for $\mathrm{Pb}$ are $1.500 \mu \mathrm{g} / \mathrm{m}^{3}$ and $0.5 \mu \mathrm{g} / \mathrm{m}^{3}$ respectively and these values are far below the concentrations got in the study areas. Lead remains the major trace element in urban environment due to its long residence time in the environment [Olowoyo and van Herdeen, 2010]. The high concentrations of $\mathrm{Pb}$ got in the study areas exceeded the FEPA and EC recommended limits of $0.005 \mathrm{mg} / \mathrm{l}$ and $0.5 \mu \mathrm{g} / \mathrm{l}$ respectively and this is noted to be always associated with high traffic density, which increases the availability of $\mathrm{Pb}$ by release through the exhausts of motor vehicles. This signals that high levels of $\mathrm{Pb}$ are still released or re-suspended by vehicular traffic [Odukoya et al., 2000). Scerbo et al. (2001)] noted that vehicular emission seems to be the major source of atmospheric $\mathrm{Pb}$.

Maximum average concentration of lead found in traffic and industrial area at location T-2 $\left(2.9 \mu \mathrm{g} / \mathrm{m}^{3}\right)$ and I-3 
$\left(2.9 \mu \mathrm{g} / \mathrm{m}^{3}\right)$. The average $\mathrm{Pb}$ concentration varied from $1.1 \mu \mathrm{g} / \mathrm{m}^{3}$ at residential area (R-3) to $2.7 \mu \mathrm{g} / \mathrm{m}^{3}$ at commercial area (C-1) (Table-3). The lowest value among these thirteen locations was found at location R-3 (residential area) and PCSIR campus UB-1 (background area), whereas the highest value was observed at location I-3 (industrial area). The higher $\mathrm{Pb}$ concentration at the industrial areas may be due to the large parking place of vehicles near this round about with very high traffic density and different industrial emission. However, the atmospheric $\mathrm{Pb}$ concentration in Karachi is decreasing gradually, presumably due to the ban on leaded gasoline in Karachi. Whereas, previously deposited lead concentration in the environment is a main source of lead in present environment. Even though the concentration of lead decreases in the gasoline but due to increase of vehicles in the city also increase the emission of lead in the environment of the city.

Figure-3 shows the concentration of Manganese in Residential, traffic, commercial Industrial and background areas of Karachi. Maximum average concentration of manganese $\left(3.0 \mu \mathrm{g} / \mathrm{m}^{3}\right)$ found at location $\mathrm{C}-1$ (commercial area). The average Mn concentrations varied from $0.5 \mu \mathrm{g} / \mathrm{m}^{3}$ at location R-3 residential area to $3.0 \mu \mathrm{g} / \mathrm{m}^{3}$ at location C-1 commercial area (Table 3). The highest value of $\mathrm{Mn}$ at location C-1 (super Market was probably due to very high traffic density.

Figure-4 shows the concentration of Copper in Residential, traffic, Commercial, Industrial and background areas of Karachi. Maximum average concentration of copper $\left(3.1 \mu \mathrm{g} / \mathrm{m}^{3}\right)$ found at location I-3 (industrial area). The average $\mathrm{Cu}$ concentrations varied from $1.0 \mu \mathrm{g} / \mathrm{m}^{3}$ at location $\mathrm{R}-1$ in residential area to $3.1 \mu \mathrm{g} / \mathrm{m}^{3}$ at location $\mathrm{I}-3$ in industrial area (Table 3). The highest value of $\mathrm{Cu}$ at location I-3 was probably due to large parking place of vehicles near this round about with very high traffic density and various industrial emission sources. Copper in the environment is attributed to vehicular emissions /oil combustion and resuspended road dust [Farmaki and Thomaidis, 2008]. Wang et al. (2009) also related the presence of copper to chemical industries and intensive traffics. The high emissions of vehicles, often old richety vehicles and abundance of industries in the study areas accounted for the high level of copper.

Figure- 5 shows the concentration of Nickel in Residential, traffic, Commercial, Industrial and background areas of Karachi. Maximum average concentration of nickel $\left(2.6 \mu \mathrm{g} / \mathrm{m}^{3}\right)$ found at location I-2 (industrial area). The average Ni concentrations varied from $1.1 \mu \mathrm{g} / \mathrm{m}^{3}$ at location $\mathrm{R}-3$ in residential area to $2.6 \mu \mathrm{g} / \mathrm{m}^{3}$ at location $\mathrm{I}-3$ in industrial area (Table 3). The highest value of $\mathrm{Ni}$ at location I-3 was probably due to industrial emission and very high traffic density at this location.

Nickel is emitted through combustion of plants as nickel sulfate and oxidic nickel (EC, 2001). Nickel was highly abundant in this study and it is a fact that the introduction into the environment was man-made. The wide range of trade involving using/repairing components or devices containing
$\mathrm{Ni}$ or its alloys especially stainless steel (alloy wheel in cars) has apparently increased its concentrations in the environment. Incineration of municipal garbage and sewage sludge has also been confirmed to account for $\mathrm{Ni}$ existence in the environment. The rate of smoking these days in urban areas has also contributed to the high Ni concentration. WHO (2000) asserted that mainstream cigarette smoke contains 0.04- $0.58 \mathrm{microgramsNi} /$ cigarette and consuming 20 cigarette/day will increase the ambient $\mathrm{Ni}$ value by 15 times. It is possible that the high population of smokers in Nigeria has added to Ni pollution because the concentrations in the study areas are far greater than the recommended WHO guidelines for air quality which is between $1-180 \mu \mathrm{g} / 1$ [WHO, 2000].

The average concentrations of copper, manganese and nickel are of same order of the magnitude. These metals are released during different operations of the road transport such as combustion, component wear, fluid leakage and corrosion of batteries and metallic parts such as radiators etc [Dolan et al, 2006].

Figure-6 shows the concentration of cadmium in Residential, traffic, commercial, industrial and background areas of Karachi. The high cadmium concentration detected indicates the ubiquity of this toxic metal in the environment and shows that the areas are cadmium-polluted. According to Federal Environmental Protection Agency (1988), European Communities (2001) and World Health Organization (2000), the recommended atmospheric limit for $\mathrm{Cd}$ are $0.003 \mathrm{mg} / \mathrm{l}$, $5 \mathrm{ng} / \mathrm{l}$, and $0.02 \mathrm{mg} / \mathrm{l}$ respectively and these values are far below the concentrations got in the study areas. $\mathrm{Cd}$ in the environment in low concentration could be from natural sources but the other probable sources of $\mathrm{Cd}$ in this study may be through anthropogenic activities. Awofolu (2005) puts forward that the largest source of $\mathrm{Cd}$ release to the environment is from industrial activities, burning of fossil fuels and incineration of municipal waste materials. This assertion was also supported by Olowoyo and van Heerden (2010) that $\mathrm{Cd}$ in the environment is traced to urban metal smelting companies, burning of household wastes and paint manufacturing industries while Scerbo et al. (2010) mentioned that $\mathrm{Cd}$ in the environment is traced to Di-methyl cadmium used in the production of tetraethyl lead and it is emitted by vehicles. The presence of industries and several combustion processes like vehicular emissions contributed to the atmospheric $\mathrm{Cd}$ in the study.

Maximum average concentration of cadmium found in industrial area at location I-3 $\left(0.151 \mu \mathrm{g} / \mathrm{m}^{3}\right)$. This high concentration of cadmium may be due to the large parking place of vehicles near this round about with very high traffic density. Average $\mathrm{Cd}$ concentrations in this study ranged from 0.028 to $0.151 \mu \mathrm{g} \mathrm{m}^{-3}$. The lowest value among these thirteen locations was found at location UB-1 in urban background area, whereas the highest value was observed at location I-3 in industrial area. The higher $\mathrm{Cd}$ concentration at the industrial areas may be due to the release of $\mathrm{Cd}$ from different industrial mechanical processes and also due to heavy traffic load. 


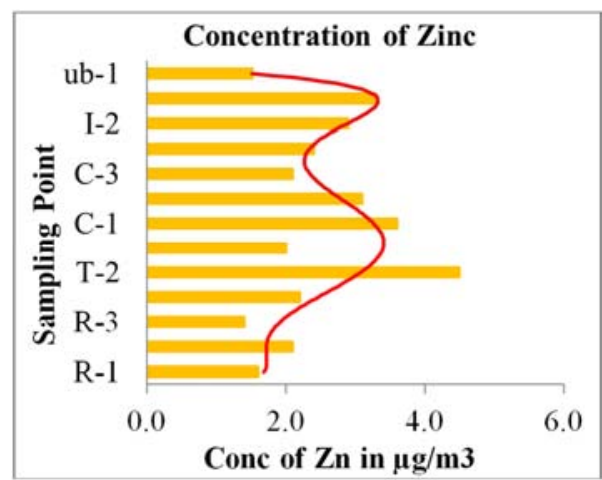

Figure 1. Concentration of Zinc.

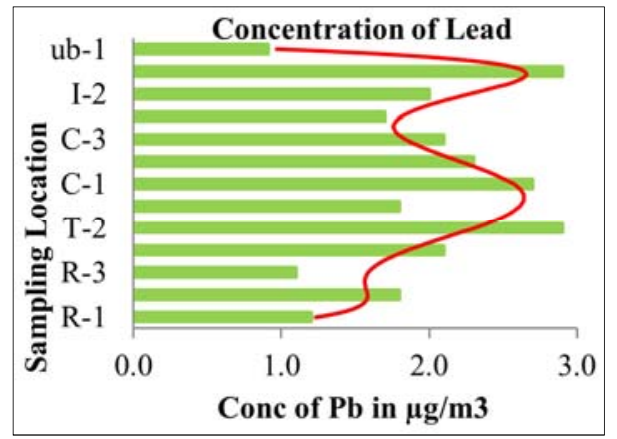

Figure 2. Concentration of Lead.

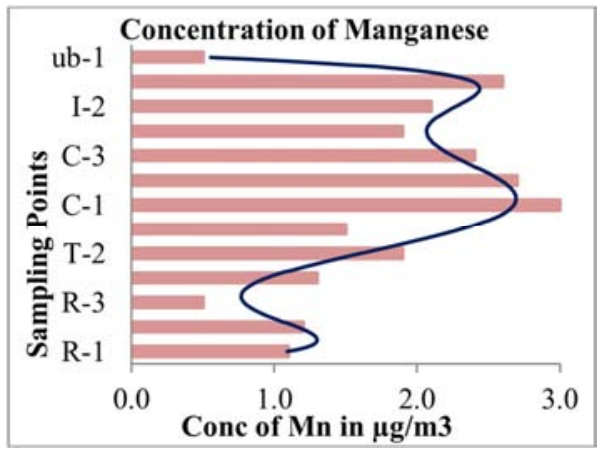

Figure 3. Concentration of Manganese.

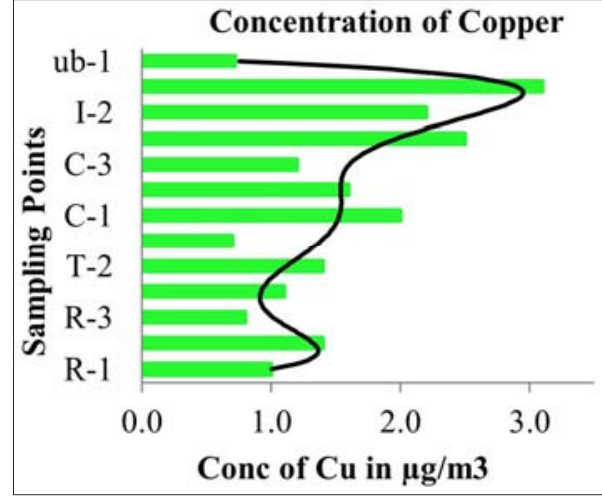

Figure 4. Concentration of Copper.

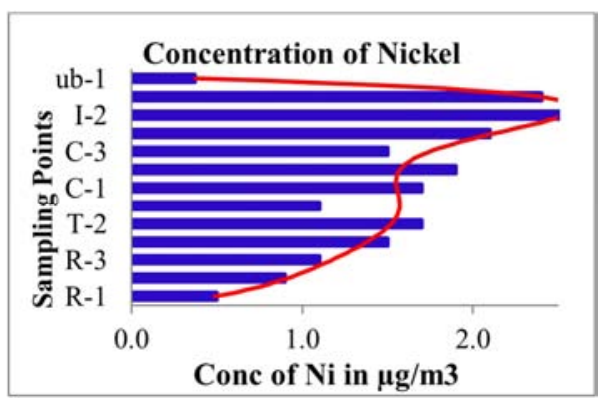

Figure 5. Concentration of Nickel.

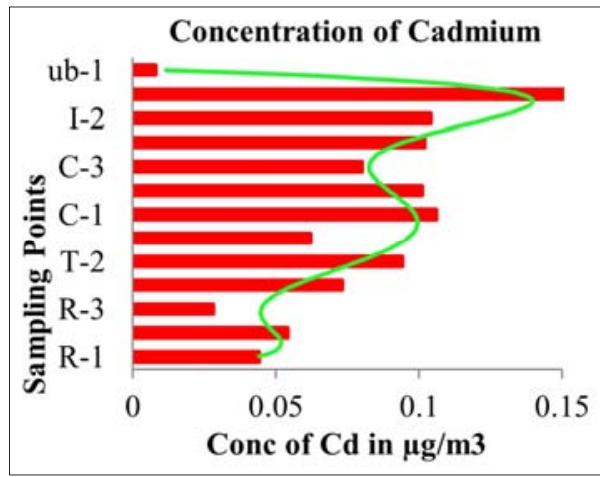

Figure 6. Concentration of Cadmium.

Table 4. Comparison of metal concentrations $\left(\mu \mathrm{g} \mathrm{m}^{3}\right)$ in $P M_{10}$ samples observed in the present study with other parts of the world.

\begin{tabular}{lllllllll}
\hline Location/Site type & Typography & $\mathbf{C d}$ & $\mathbf{P b}$ & $\mathbf{Z n}$ & $\mathbf{C u}$ & $\mathbf{M n}$ & Ni & Reference \\
\hline & Commercial & 0.10 & 2.37 & 2.93 & 1.60 & 2.70 & 1.70 & \\
Karachi, Pakistan & Residential & 0.04 & 1.37 & 1.73 & 1.07 & 0.93 & 0.83 & Present Study \\
& Industrial & 0.12 & 2.20 & 2.87 & 2.60 & 2.20 & 2.37 & \\
Delhi, India, & U-background & 0.008 & 0.91 & 1.50 & 0.72 & 0.50 & 0.37 & \\
Coimbatore, India & Residential & $0.01-0.02$ & $0.27-0.46$ & $4.1-4.7$ & $0.18-0.27$ & $0.25-0.32$ & $0.28-0.37$ & Khillare and Sarkar, (2012) [15] \\
Agra, India & Residential & BDL & $0.21-0.62$ & $11.3-20.7$ & $0.7-0.77$ & NR & $0.16-0.22$ & Vijayanand et al., (2008) [16] \\
Delhi, India & Urban & NR & 1.1 & 0.5 & 0.1 & 0.9 & 0.2 & Kulshrestha et al., (2009) [18] \\
Lahore, Pakistan & Urban & 0.01 & 0.44 & 4.7 & 3.7 & 0.74 & 0.15 & Shridhar et al., (2010) [19] \\
Beijing, China & Resan & 0.08 & 4.4 & 11 & 0.07 & 0.3 & 0.02 & von Schneidemesser et al.,(2010) \\
Tocopilla, Chile & Residential & 0.005 & 0.33 & 0.64 & 0.09 & 0.21 & 0.01 & Khan et al., (2010) [20] \\
Istanbul, Turkey & Nrban & 0.001 & 0.01 & 0.01 & 1.1 & 0.06 & 0.0009 & Jorquera, (2009) [21] \\
Lecce, ttaly & U-background & NR & 0.008 & 0.24 & 0.02 & 0.02 & 0.007 & Theodosi et al., (2010) [22] \\
Vienna, Austria & Urban & 0.0005 & 0.01 & 0.04 & 0.01 & 0.008 & 0.003 & Contini et al., (2010) [23] \\
Bratislava, Slovakia & Urban & 0.0001 & 0.02 & 0.03 & 0.008 & 0.01 & 0.006 & Limbeck et al., (2009) [24] \\
Huelva, Spain & Urban & 0.0006 & 0.02 & 0.03 & 0.05 & 0.01 & 0.0005 & Meresova et al., (2008) [25] \\
Edinburgh, UK & U-background & 0.0003 & 0.01 & 0.01 & 0.005 & 0.003 & 0.003 & Sanchez de la Campa et al., [26] (2007) \\
Los Angeles, USA & Urban & NR & 0.002 & 0.004 & 0.003 & 0.002 & 0.0006 & Singh et al., (2005) [27] \\
& & & & & & & &
\end{tabular}


Table 5. Comparison of metal concentrations $\left(\mu \mathrm{g} \mathrm{m}^{3}\right)$ in $P M_{10}$ samples observed in the present study with USEPA and WHO guidelines.

\begin{tabular}{|c|c|c|c|c|c|c|}
\hline & $\begin{array}{l}\text { Commercial } \\
\text { (present study) }\end{array}$ & $\begin{array}{l}\text { Residential } \\
\text { (present study) }\end{array}$ & $\begin{array}{l}\text { Industrial (present } \\
\text { study) }\end{array}$ & $\begin{array}{l}\text { U-background } \\
\text { (present study) }\end{array}$ & WHO & USEPA \\
\hline & $\mu \mathrm{g} / \mathrm{m}^{3}$ & $\mu \mathrm{g} / \mathrm{m}^{3}$ & $\mu \mathrm{g} / \mathrm{m}^{3}$ & $\mu \mathrm{g} / \mathrm{m}^{3}$ & $\mu \mathrm{g} / \mathrm{m}^{3}$ & $\mu \mathrm{g} / \mathrm{m}^{3}$ \\
\hline $\mathrm{Pb}$ & 2.37 & 1.37 & 2.23 & 0.91 & 0.500 & 1.500 \\
\hline $\mathrm{Zn}$ & 2.93 & 1.70 & 2.87 & 1.50 & ----- & ------ \\
\hline $\mathrm{Cu}$ & 1.60 & 1.07 & 2.60 & 0.72 & --------- & ----- \\
\hline $\mathrm{Mn}$ & 2.70 & 0.93 & 2.20 & 0.50 & 0.150 & 0.500 \\
\hline $\mathrm{Ni}$ & 1.70 & 0.83 & 2.37 & 0.37 & 0.0038 & 0.0024 \\
\hline $\mathrm{Cd}$ & 0.10 & 0.04 & 0.12 & 0.008 & 0.005 & 0.006 \\
\hline
\end{tabular}

Table-3 shows that various studies on Trace metals (cadmium, zinc, lead, manganese, copper and nickel) level in $\mathrm{PM}_{10}$ samples have been undertaken in different countries of the world. Khillare and Sarkar (Khillare and Sarkar; 2012) reported the $\mathrm{Pb}$ concentration in particulate matter in urban residential areas within the range 0.27 to $0.46 \mu \mathrm{g} / \mathrm{m}^{3}$. In the present study (Table-3) average concentration of lead in residential areas was recorded $1.37 \mu \mathrm{g} / \mathrm{m}^{3}$ which is higher from Delhi, India (Khillare and Sarkar; 2012), Coimbatore, India (Vijayanand et al., 2008), Beijing China (Khan et al; 2010) and Tocopilla, Chile (Jorquera; 2009), in urban background areas was recorded as $0.91 \mu \mathrm{g} / \mathrm{m}^{3}$, which is higher than that reported for urban background of Lecce, Italy (Contini et al., 2010) and UK (Heal et al; 2005). Level of trace metals like (cadmium, zinc, lead, manganese, copper and nickel) also analyzed in the samples collected from industrial and commercial areas of Karachi city. The average concentration of lead in industrial areas was found to be $2.20 \mu \mathrm{g} / \mathrm{m}^{3}$ whereas in commercial areas of Karachi was found to be $2.37 \mu \mathrm{g} / \mathrm{m}^{3}$ respectively.

Khillare and Sarkar (Khillare and Sarkar; 2012) also reported the concentration of cadmium in particulate matter range from 0.01 to $0.02 \mu \mathrm{g} / \mathrm{m}^{3}$. Table- 3 shows that, in the present study the average concentration of $\mathrm{Cd}$ in residential areas was recorded as $0.04 \mu \mathrm{g} / \mathrm{m}^{3}$ which is higher from Delhi, India (Khillare and Sarkar; 2012), Coimbatore, India (Vijayanand et al., 2008), Beijing China (Khan et al; 2010) and Tocopilla, Chile (Jorquera; 2009), in urban background areas was recorded as $0.008 \mu \mathrm{g} / \mathrm{m}^{3}$ which is higher than that reported for urban background of Italy (Contini et al., 2010) and UK (Heal et al; 2005), in industrial areas was found to be $0.12 \mu \mathrm{g} / \mathrm{m}^{3}$ whereas in commercial areas of Karachi was found to be $0.10 \mu \mathrm{g} / \mathrm{m}^{3}$ respectively.

Khillare and Sarkar (Khillare and Sarkar; 2012) also reported the concentration of zinc, manganese, copper and nickel in particulate matter range from $4.1-4.7 \mu \mathrm{g} / \mathrm{m}^{3}(\mathrm{Zn})$, $0.25-0.32 \mu \mathrm{g} / \mathrm{m}^{3} \quad(\mathrm{Mn}), \quad 0.18-0.27 \mu \mathrm{g} / \mathrm{m}^{3} \quad(\mathrm{Cu})$ and $0.28-$ $0.37 \mu \mathrm{g} / \mathrm{m}^{3}(\mathrm{Ni})$ respectively. Table-3 shows that, in the present study the average concentration of $\mathrm{Zn}$ in residential area was recorded as $1.70 \mu \mathrm{g} / \mathrm{m}^{3}$ which is lower from Delhi, India (Shridhar et al; 2010), Coimbatore, India (Vijayanand et al., 2008), and higher from Beijing Chin (Khan et al; 2010) and Tocopilla, Chile (Jorquera; 2009), in urban background areas was recorded as $1.52 \mu \mathrm{g} / \mathrm{m}^{3}$ which is higher than that reported for urban background of Lecce, Italy (Contini et al., 2010) and UK (Heal et al; 2005), in industrial areas was found to be
$2.87 \mu \mathrm{g} / \mathrm{m}^{3}$ whereas in commercial areas of Karachi was found to be $2.93 \mu \mathrm{g} / \mathrm{m}^{3}$ respectively. $\mathrm{Mn}$ in residential area was recorded as $0.93 \mu \mathrm{g} / \mathrm{m}^{3}$ which is higher from Delhi, India (Khillare and Sarkar; 2012), Coimbatore, India (Vijayanand et al., 2008), Beijing China (Khan et al; 2010) and Tocopilla, Chile (Jorquera; 2009), in urban background areas was recorded as $0.50 \mu \mathrm{g} / \mathrm{m}^{3}$ which is higher than that reported for urban background of Italy (Contini et al., 2010) and UK (Heal et al; 2005), in industrial areas was found to be $2.20 \mu \mathrm{g} / \mathrm{m}^{3}$ whereas in commercial areas of Karachi was found to be $2.70 \mu \mathrm{g} / \mathrm{m}^{3}$ respectively. $\mathrm{Cu}$ in residential area was recorded as $1.07 \mu \mathrm{g} / \mathrm{m}^{3}$ which is higher from Delhi, India (Khillare and Sarkar; 2012), Coimbatore, India (Vijayanand et al., 2008), almost equal to Beijing China (Khan et al; 2010) and also higher from Tocopilla, Chile (Jorquera; 2009), in urban background areas was recorded as $0.72 \mu \mathrm{g} / \mathrm{m}^{3}$ which is higher than that reported for urban background of Italy (Contini et al., 2010) and UK (Heal et al; 2005), in industrial areas was found to be $2.60 \mu \mathrm{g} / \mathrm{m}^{3}$ whereas in commercial areas of Karachi was found to be $1.60 \mu \mathrm{g} / \mathrm{m}^{3}$ respectively. $\mathrm{Ni}$ in residential area was recorded as $0.83 \mu \mathrm{g} / \mathrm{m}^{3}$ which is higher from Delhi, India (Khillare and Sarkar; 2012), Coimbatore, India (Vijayanand et al., 2008), Beijing China (Khan et al; 2010) and Tocopilla, Chile (Jorquera; 2009), in urban background areas was recorded as $0.37 \mu \mathrm{g} / \mathrm{m}^{3}$ which is higher than that reported for urban background of Italy (Contini et al., 2010) and UK (Heal et al; 2005), in industrial areas was found to be $2.37 \mu \mathrm{g} / \mathrm{m}^{3}$ whereas in commercial areas of Karachi was found to be $1.70 \mu \mathrm{g} / \mathrm{m}^{3}$ respectively.

\section{Conclusions}

Atmospheric pollution at thirteen locations in Karachi, Pakistan, was characterized in terms of trace gases, PM, and trace metals. The average concentration of $\mathrm{SO}_{2}$ and $\mathrm{NO}_{2}$ at thirteen sampling locations in Karachi are higher to the annual average of the World Health Organization's (WHO) guideline values probably due to the high content of sulfur in fossil fuel and high traffic density whereas concentration of $\mathrm{CO}$ is lower than WHO guideline values. Overall mean concentration of $\mathrm{PM}_{10}$ at various locations of commercial, residential, industrial and background areas was $207.8 \mu \mathrm{g} \mathrm{m}^{-3}$ for Karachi region.

Elevated concentrations of PM were observed in Karachi city, but these were still lower than those reported for Southeast Asian sites. The $\mathrm{PM}_{10}$ mass-concentrations in 
Kanpur, India were almost equal than those were found for Karachi. At three sampling locations in Kanpur, the average $\mathrm{PM}_{10}$ mass concentration was $211 \mu \mathrm{g} \mathrm{m}^{-3}$ and ranged from 80 to $281 \mu \mathrm{g} \mathrm{m}^{-3}$ (Sharma and Maloo 2005). The level of $\mathrm{PM}_{10}$ in Karachi shows that particulate mass mostly derived from fine fraction, which is very harmful for human health.

The concentrations of $\mathrm{Zn}, \mathrm{Pb}, \mathrm{Mn}, \mathrm{Cu}, \mathrm{Ni}$ and $\mathrm{Cd}$ were much lower than the previous measurements in Karachi city. In particular, the $\mathrm{Pb}$ concentration is decreasing due to ban of leaded fuel in Karachi, Pakistan.

\section{References}

[1] A. J. McMichael, 2000. The urban environment and health in a world of increasing globalization issues for developing countries, Bulletin of World Health Organization, Special theme "Environment and Health, 78 (9), 111-7.

[2] Sicard, P., Lesne, O., Alexandre, N., Mangin, A., Collomp, R. 2011. Air Quality Trends and Potential Health Effects Development of an Aggregate Risk Index. Atmos. Environ, 45, 1145-1153.

[3] Brook RD, Rajagopalan S, Pope CA, Brook JR, Bhatnagar A, Diez-Roux AV, Holguin F, Hong Y, Luepker RV, Mittleman MA, Peters A, Siscovick D, Smith SC, Whitsel L, Kaufman JD: 2010. Particulate matter air pollution and cardiovascular disease: an update to the scientific statement from the American heart association. Circulation, 121: 2331-2378.

[4] Park, S. S., Kim, Y. J., 2005. Source contributions to fine particulate matter in an urban atmosphere. Chemosphere 59, 217-226.

[5] IPCC (International Panel on Climate Change), 2001, The third assessment report of Working Group I of the Intergovernmental Panel on Climate Change. Technical summary. IPCC, Shanghai.

[6] Sajjad, S. H, Blond N, clapper A, Asif Raza, 2010, Preliminary Study of Urbanization, Fossil fuels consumptions and $\mathrm{CO}_{2}$ emission in Karachi, African journal of Biotechnology, 9 (13), 1941-1948.

[7] Olowoyo, J. O., van Heerden, E. (2010), Trace element concentrations from lichen transplants in Pretoria, South Africa.- Envirn. Sci. Pollut. Res. DOI 10.1007/s11356-0100410-3.

[8] Odukoya, O. O., Arowolo, T. A., Bamgbose, O. (2000), Pb, Zn and $\mathrm{Cu}$ levels in tree barks as indicator of atmospheric pollution.- Environ. Int. 26: 11-16

[9] Scerbo, R., Ristori, T., Possenti, L., Lampugnami, L., Barale, R., Barghigiani, C. (2001), Lichen (Xanthoria parientina) biomonitoring of trace element contamination and air quality assessment in Pisa Province, Italy. Sci. -Total Environ. 286: 27-40

[10] Farmaki, E. G., Thomaidis, N. S. (2008), Current status of the metal pollution of the environment of Greece- a review.Global Nest 10 (3): 366-375

[11] Wang, Z. M., Song, K. S., Zhang, B., Liu, D. W., Ran, C. Y., Zhang, S. M., Luo, L., Zhang, C. H. (2009), Spatial variability and affecting factors of soil nutrients in cropsland of Northeast China.- Plant, Soil and Plant 55: 110-120
[12] World Health Organization. (2000), Air quality guidelines for Europe.- WHO Regional Publication, European series No 91, Copenhagen.

[13] Dolan L. M. J, Van Bohemen H, Whelan P, Akbar K. F, O' Malley V, O' Leary G, Keizer P. J, (2006), Towards the sustainable development of modern road ecosystem. In: Davenport J, Davenport J. L (eds). The Ecology of Transportation Managing Mobility for Environment. Springer Netherlands $275-331$.

[14] Awofolu, O. R. (2005), A survey of trace metals in vegetation, soil and lower animal along some selected major roads in metropolitan city of Lagos.- Environmental Monitoring and Assessment 105: 431-447.

[15] Pandit S. Khillare, Sayantan Sarkar, 2012. Airborne inhalable metals in residential areas of Delhi, India: distribution, source apportionment and health risks, Atmospheric Pollution Research. 3; 46-54.

[16] Vijayanand, C., Rajaguru, R., Kalaiselvi, K., Selvam, K. P., Palanivel, M. 2008. Assessment of heavy metal contents in the ambient air of the Coimbatore city, Tamilnadu, India. Journal of Hazardous Materials 160, 548-553.

[17] Kulshrestha, A., Satsangi, P. G., Masih, J., Taneja, A. 2009. Metal concentration of $\mathrm{PM}^{\prime} .5$ and $\mathrm{PM}_{\mathrm{O}}$ particles and seasonal variations in urban and rural environment of Agra, India. Science of the Total Environment, 407, 6196-6204.

[18] Shridhar, V., Khillare, p. s., Agarwal, T., Ray, S. 2010. Metallic species in ambient particulate matter at rural and urban location of Delhi. Journal of Hazardous Materials 175, 600-607.

[19] Von Schneidemesser, E., Stone, LA., Quraishi, T. A., Shafer, M. M., Schauer, J. J. 2010. Toxic metals in the atmosphere in Lahore, Pakistan. Science of the Total Environment 408, 16401648 .

[20] Khan, M. F., Hirano, K., Masunaga. 2010. Quantifying the sources of hazardous elements of suspended particulate matter aerosol collected in Yokohama, Japan. Atmospheric Environment 44, 2646-2657.

[21] Jorquera, H. 2009. Source apportionment of $\mathrm{PM}_{\mathrm{lO}}$ and PM, 5 at Tocopilla, Chile $\left(22^{\circ} 05^{\prime} 5,70012^{\prime} \mathrm{W}\right)$. Environmental Monitoring and Assessment, 153, 235-251.

[22] Theodosi, C., 1m, U., Bougiatioti, A., Zarmpas, P., Yenigun, 0., Mihalopoulos, N. 2010. Aerosol chemical composition over Istanbul. Science of the Total Environment, 408, 24822491.

[23] Contini, D., Genga, A., Cesari, D., Siciliano, M., Donateo, A., Bove, M. C., Guascito, M. R. 2010. Characterisation and source apportionment of $\mathrm{PM}_{1 \mathrm{O}}$ in an urban background site in Lecce. Atmospheric Research, 95, 40-54.

[24] Limbeck, A., Handler, M., Puis, c., Zbiral, J., Bauer, H., Puxbaum, H. 2009. Impact of mineral components and selected trace metals on ambient $\mathrm{PM}_{\mathrm{O}}$ concentrations. Atmospheric Environment, 43, 530-538.

[25] Meresova, J., Florek, M., Holy, K., Jeskovsky, M., Sykora, I., Frontasyeva, M. V. Pavlov, 5.5., Bujdos, M. 2008. Evaluation of elemental content in air-borne particulate matter in lowlevel atmosphere of Bratislava. Atmospheric Environment, 42, 8079-8085. 
[26] Sanchez de la Campa, A. M., de la Rosa, L, Querol, X., Alastuey, A., Mantilla, E. 2007. Geochemistry and origin of $\mathrm{PM}_{1 \mathrm{O}}$ in the Huelva region, Southwestern Spain. Environmental Research, 103, 305-316.

[27] Heal, M. R., Hibbs, L. R., Agius, R. M., Beverland, L. J. 2005. Total and water soluble trace metal content of urban background $\mathrm{PM}_{1 \mathrm{O}}, \mathrm{PM}_{2.5}$ and black smoke in Edinburgh, UK. Atmospheric Environment, 39, 1417-1430.

[28] Singh, M., Jaques, P. A., Sioutas, C. 2002. Size distribution and diurnal characteristics of particle-bound metals in source and receptor sites of the Los Angeles basin. Atmospheric Environment, 36, 1675-1689. 